z vykorystanniam praimeriv dlia vyiavlennia Trichomonas vaginalis, Trichomonas tenax ta Pentatrichomonas hominis [Comparison of Trichomoniasis diagnostic effectiveness by culture method and polymer chain reaction method using primers to detect Trichomonas vaginalis, Trichomonas tenax and Pentatrichomonas hominis]. Ukrainskyi zhurnal dermatolohii, venerolohii, kosmetolohii, 1 (64), 65-69.

[20] Fedorych, P. V., Zelenyi, S. B. (2016). Pat. 110759 UA. Sposib vyznachennia prysutnosti Pentatrichomonas hominis u doslidzhuvanomu zrazku ta nabir praimeriv dlia yoho zdiisnennia [Method for determining the presence of Pentatrichomonas hominis in the test sample and the set of primers for its implementation.]. MPK S12Q1/68 (2006.01), S12Q1/04 (2006.01), S12N15/11 (2006.01), S12R1/90 (2006.01). No. a201501255; declareted: 16.02.2015; published: 10.02.16, Bul. No. 3.

[21] Lyisak, V. V., Fomina, O. V. (2014). Sistematika mikroorganizmov [Systematization of microorganisms]. Minsk: BGU, 304.

[22] Meloni, D., Mantini, C., Goustille, J., Desoubeaux, G., Maakaroun-Vermesse, Z., Chandenier, J. et. al. (2011). Molecular identification of Pentatrichomonas hominis in two patients with gastrointestinal symptoms. Journal of Clinical Pathology, 64 (10), 933-935. doi: http://doi.org/10.1136/jcp.2011.089326

[23] Mehr, A. K., Zarandi, A., Anush, K. (2015). Prevalence of Oral Trichomonas tenax in Periodontal Lesions of Down Syndrome in Tabriz, Iran. Journal of Clinical and Diagnostic Research, 9 (7), 88-90. doi: http://doi.org/10.7860/jcdr/2015/14725.6238

[24] Marty, M., Lemaitre, M., Kemoun, P., Morrier, J. J., Monsarrat, P. (2017) Trichomonas tenax and periodontal diseases: a concise review Parasitology, 144 (11), 1417-1425. doi: http://doi.org/10.1017/ s0031182017000701

\title{
ESTIMATION OF RESERVES FOR IMPROVING THE RESULTS OF PATIENTS WITH MULTIPRESISTANT PULMONARY TUBERCULOSIS IN THE APPLICATION OF SURGICAL METHODS BASED ON ANALYSIS OF THE EFFICIENCY OF CONSERVATIVE TREATMENT OF A SPECIFIED COHORT
}

\author{
Oleg Khmel \\ Department of Surgical Treatment of Tuberculosis and NLL \\ State Enterprise "F. G. Yanovsky National Institute of Phthisiology and Pulmonology of \\ NAMS of Ukraine" \\ 10 M. Amosova str., Kyiv, Ukraine, 03680 \\ Khmel.Ol@gmail.com \\ Igor Kalabukha \\ Department of Thoracic Surgery \\ State Enterprise "F. G. Yanovsky National Institute of Phthisiology and Pulmonology of \\ NAMS of Ukraine“ \\ 10 M. Amosova str., Kyiv, Ukraine, 03680 \\ dr.kalabukha@gmail.com \\ Vladimir Ivashchenko \\ Department of Thoracic Surgery \\ State Enterprise "F. G. Yanovsky National Institute of Phthisiology and Pulmonology of \\ NAMS of Ukraine“" \\ 10 M. Amosova str., Kyiv, Ukraine, 03680 \\ ivaschenko@ifp.kiev.ua
}




\begin{abstract}
In order to improve the results of treatment of patients with multi-resistant pulmonary tuberculosis with the use of surgical methods, the effectiveness estimation of conservative treatment of 176 patients with this form of tuberculosis according to cohort analysis data in two districts of Kyiv were done.

In the list were included following parameters: type of the tuberculosis, its clinical-radiological form and the prevalence of the process, the results of conservative treatment in patients who completely finished the course of anti-TB chemotherapy and the results of conservative treatment of 81 patients who had indications for surgical treatment but had not been operated. Processing of the materials of the study was carried out with the use of licensed software products included in the Microsoft Office Professional 2007 package. The predicted results of treatment were calculated on the condition of surgical intervention.

Out of the total sample of patients, $31.3 \%$ of the patients completed treatment. Mortality was $16.5 \%$, transferred to palliative care $11.9 \%$. More than one in three patients (35.2\%) stopped treatment at different times from the start.

According to the clinic of thoracic surgery SU "National Institute of Phthisiology and Pulmonology named after F. G. Yanovsky NAMS of Ukraine", the overall effectiveness of treatment for patients with limited multidrug-resistant tuberculosis with the use of surgical intervention is about $95 \%$ in the absence of mortality. We have modelled the potential results of treatment of the selected cohort in case of the surgical stage is fully and timely applied in a complex of therapeutic treatment. If all 81 patients with indications for surgical treatment used that way, then, with the above efficiency, a complete cure could be predicted in 77 patients ( $44.5 \%$ of the total number of observations), which in turn would allow predicting the achievement completion of treatment at $64.2 \%$ with complete cure for $60.6 \%$ of patients.

Thus, it is established that the positive result of surgical treatment in the general complex of treatment measures in patients with multidrug-resistant pulmonary tuberculosis is able to improve the results of treatment of this contingent more than twice, reduce the mortality almost by three times, reduce the need for repeated courses of treatment from $7.4 \%$ to $1.7 \%$, as well as to reduce the epidemiological reservoir of infection due to a significant decrease in the number of patients with failure to treat tuberculosis, interrupted and palliative treatment.
\end{abstract}

Keywords: tuberculosis, lungs, multidrug resistance, surgical treatment.

DOI: $10.21303 / 2504-5679.2018 .00737$

(C) Oleg Khmel, Igor Kalabukha, Vladimir Ivashchenko

\title{
1. Introduction
}

In the treatment of pulmonary tuberculosis, which is accompanied by irreversible morphological changes in the pulmonary tissue [1, 2], surgical methods are a priority [3]. At the same time, chemoresistance of mycobacterium tuberculosis (MBT) is increasingly inducing the expanded use of surgical methods for treating patients in this category [4, 5], since conservative methods for treating patients with a common destructive multidrug-resistant pulmonary tuberculosis do not meet current requirements [6] and provide complete cure, on average, only in $8.0 \%$ of cases [7]; the lethal outflow during the course of the main course of treatment for caseous pneumonia is $64.3-76.4 \%$ of cases [8,9]. According to the available data [10], despite significant drugs and various methods of chemotherapy, treatment of multiple/polysaccharide destructive tuberculosis is unsatisfactory: after more than 3 months of therapy, the smear conversion was observed in only a quarter of patients, with only $14.3 \%$ of them it corresponded to the improvement of clinical and radiological data $[11,12]$.

Drug resistance is, at present, the main challenge in global control of tuberculosis in connection with the small selection of treatment methods [13, 14]. In general, surgery has proven effective in treating patients with multi-resistant tuberculosis. Accordingly, a combined therapeutic and surgical approach is increasingly used to treat these patients $[15,16]$.

At the same time, the contingents of patients who were treated with the use of surgical methods are significantly different [17]. Accordingly, there are significant differences in the assessment of the effectiveness of the use of surgery in the complex treatment of patients with pulmonary tuberculosis in general and chemo-resistant in particular [18]. There was accumulated essential experience of surgical treatment of patients with common and complicated tuberculosis [19]. The feasibility and effectiveness of treatment of local forms of pulmonary tuberculosis is not well understood [20]. Argumentative issue remains the expediency of surgical treatment of patients with significant X-ray manifestations of the tuberculosis process in the absence of 
destruction, in the absence of bacterial separation, or its termination on the background of conservative treatment. The need for solving these issues has been recognized as one of the priority tasks of phthisiology and, in particular, phthisiosurgery, at the level of the World Health Organization $[21,22]$.

\section{Aim of the research}

Estimation of reserves for improvement of the treatment of patients with limited forms of multi-resistant pulmonary tuberculosis in the application of surgical methods.

\section{Materials and methods}

An evaluation of the effectiveness of treatment for patients with multidrug-resistant pulmonary tuberculosis (MDR-PTB) was performed based on cohort analysis data in two districts of Kyiv. The study included all 176 MDR-PTB patients and those with advanced resistant tuberculosis (ARTB) that was registered in the specified areas during 2013-2014 (general population). Surgical treatment in these patients was not performed.

In the list were included following parameters: the type of TB, its clinical-X-ray form, the prevalence of the tuberculous process, the general results of conservative treatment in patients who had completely completed the course of anti-TB chemotherapy, the results of conservative treatment in patients who had indications for surgical treatment separately and in relation to overall results in the general population.

Based on the allocation of contingent with indications for surgical treatment, a separate analysis of treatment outcomes in this subgroup, their impact on overall outcomes, and, based on the known efficacy of surgical treatment, a prediction of possible efficacy with adequate surgical application in the overall set of therapeutic measures was calculated.

Collection, storage and mathematical processing of the materials of the study were conducted using the licensed software products included in the Microsoft Office Professional 2007 package, the license Russian Academic OPEN No Level 43437596. The studies were performed with the state budget.

\section{Results}

All patients had chemoresistance, which was confirmed bacteriologically. Distribution by types of chemoresistance is presented in Table 1.

Table 1

Distribution of the examined patients by the type of resistance to anti-TB drugs

\begin{tabular}{ccc}
\hline \multirow{2}{*}{ The type of resistance } & \multicolumn{3}{c}{ Number of patients } \\
\cline { 2 - 3 } & absolute & \% \\
\hline MDR-PTB & 133 & 75.6 \\
ARTB & 43 & 24.4 \\
Total & 176 & 100.0
\end{tabular}

As can be seen from Table 1, three-quarters of patients had multi-resistance, one quarter advanced resistance.

The distribution of the examined patients depending on the type of the disease is presented in Table 2.

As follows from Table 2, according to the types of tuberculosis patients were divided into approximately equal groups: each of the types had about a quarter of the total. Somewhat predominantly patients with a failure of treatment were $27.3 \%$, slightly less was the number of patients with the case of "treatment after a pause" $19.9 \%$.

Distribution of patients according to clinical and radiological forms is presented in Table 3. 
Table 2

Distribution of surveyed patients by type of tuberculosis

\begin{tabular}{ccc}
\hline \multirow{2}{*}{ Type of pulmonary tuberculosis } & \multicolumn{2}{c}{ Number of patients } \\
\cline { 2 - 3 } & absolute & \% \\
\hline First time diagnosed tuberculosis & 46 & 26.1 \\
Tuberculosis recurrence & 47 & 26.7 \\
Failure of treatment & 48 & 27.3 \\
Treatment after a pause & 35 & 19.9 \\
Total & 176 & 100.0
\end{tabular}

Table 3

Distribution of patients according to clinical and X-ray forms of tuberculosis

\begin{tabular}{ccc}
\hline \multirow{2}{*}{ Form of tuberculosis } & \multicolumn{2}{c}{ Number of patients } \\
\cline { 2 - 3 } & absolute & \% \\
\hline Infiltrative & 99 & 56.3 \\
Fibrous-cavernous & 47 & 26.7 \\
Tuberculoma & 2 & 1.1 \\
Caseous pneumonia & 1 & 0.6 \\
Disseminated & 27 & 15.3 \\
Total & 176 & 100.0
\end{tabular}

As can be seen from Table 3, infiltrative tuberculosis with a disintegration or without disintegration in $56.3 \%$ of cases and fibro-cavernous tuberculosis in $26.7 \%$ of cases were the most frequently observed. We consider it advisable to note that only 2 patients with tuberculomas were observed $1.1 \%$, which, in our opinion, is due to the highest surgical activity in relation to the mentioned clinical and radiological forms of tuberculosis.

In the prevalence of tuberculosis, unilateral lesions prevailing at $58.5 \%$; the process in the lobe was observed in $45.5 \%$ of patients (Table 4 ).

Table 4

Distribution of surveyed patients according to the prevalence of tuberculous process

\begin{tabular}{ccc}
\hline \multirow{2}{*}{ Prevalence of tuberculous process } & \multicolumn{2}{c}{ Number of patients } \\
\cline { 2 - 3 } & absolute & 58.5 \\
\hline Unilateral lesions & 103 & 41.5 \\
Bilateral lesions & 73 & 45.5 \\
Process in one lobe & 80 & 54.5
\end{tabular}

In general, out of the number of patients examined, indications for surgical treatment had, at a minimum (patients not taken into account in bilateral processes, where the decision on the question of surgical treatment should be solved individually) 81 patients (46.3\%). The distribution of the examined patients who had indications for surgical treatment, as needed in different 
resection volumes, was as follows: sublobular resection or lobectomy was shown in 58 patients $(71.6 \%)$, combined resction or pneumonectomy - in 23 patients $(28.4 \%)$. We remind that for various non-objective reasons, surgery was not used.

The general results of the treatment of the examined patients are presented in Fig. 1. It should be noted that bacterial secretion, as a separate criterion, was not carried out, since bacterial secretion, negative clinical and radiological dynamics, and complications of the tuberculous process were exhibited as a failure. As a result, $31.3 \%$ of the patients completed the treatment among the total sample of patients who were taken into account in two districts of Kyiv. Mortality was $16.5 \%$, transferred to palliative care $11.9 \%$. More than one in three patients (35.2\%) stopped treatment at different times from the start.

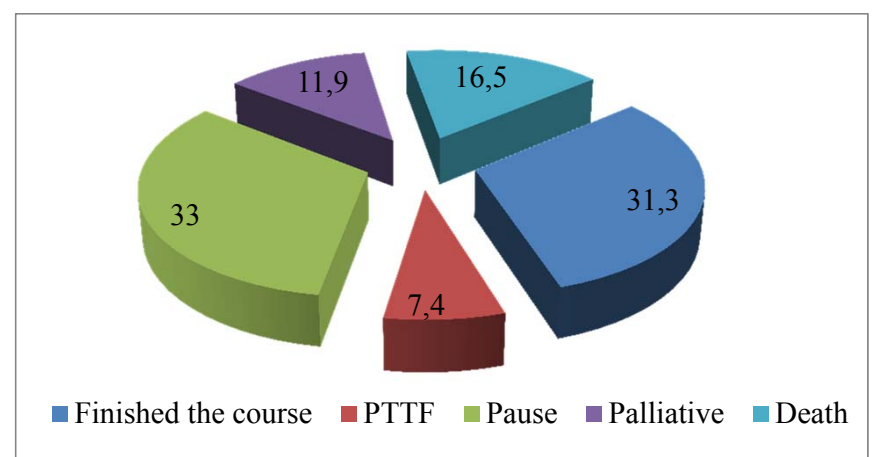

Fig. 1. Indicators of cohort analysis of the results of conservative treatment in patients with multidrug-resistant pulmonary tuberculosis

Among the patients who had indications for surgical treatment, the results of the treatment were significantly worse (Fig. 2) by the overwhelming majority of the comparison criteria. The reduction in the number of patients with a pause in treatment is most likely due to an increase in failure rates and mortality rates.

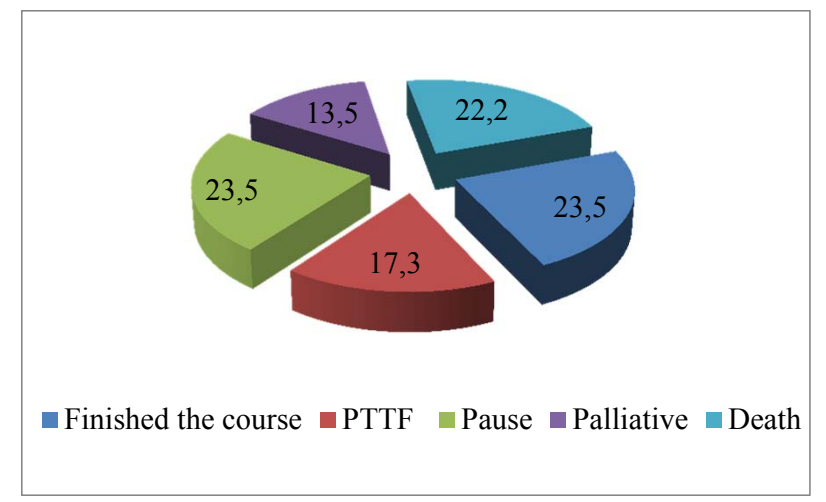

Fig. 2. Indicators of cohort analysis of the results of conservative treatment in patients with multidrug-resistant pulmonary tuberculosis, which had indications for surgical treatment

\section{Discussion}

Proceeding from the fact that according to our clinic, the overall efficacy of treatment for patients with limited multidrug-resistant tuberculosis with surgical intervention is about $95 \%$ in the absence of mortality [3], we simulated the potential outcomes of treatment of the selected contingent in case of the full and timely use of the surgical stage in a complex of medical measures. If all 81 patients with indications for surgical treatment used it, then, with the above efficiency, a complete cure could be predicted in 77 patients ( $44.5 \%$ of the total number of observations), which in turn would allow predicting the achievement completion of treatment at $64.2 \%$ with complete cure for $60.6 \%$ of patients (Fig. 3). 


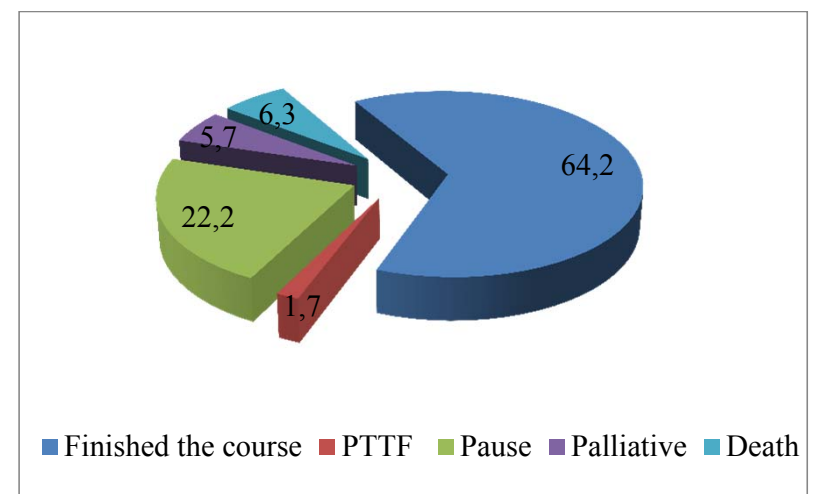

Fig. 3. Estimated (projected) indicators of cohort analysis of treatment outcomes in patients with multi-resistant pulmonary tuberculosis, provided that adequate surgical treatment is used in the overall set of therapeutic measures

\section{Conclusions}

1. Adequate use of surgical treatment in the general complex of therapeutic measures in patients with multidrug-resistant pulmonary tuberculosis can provide improved treatment results for this contingent more than twice, reduce lethality almost three times, reduce the need for repeated courses of treatment from $7.4 \%$ to $1.7 \%$.

2. The application of surgical treatment in the general complex of therapeutic measures in patients with multidrug-resistant pulmonary tuberculosis will contribute to the reduction of the epidemiological reservoir of infection due to a significant decrease in the number of patients with failure to treat tuberculosis, interrupted and palliative care.

\section{References}

[1] Blyum, N. M., Kirillov, Yu. V., Elkin, A. V., Ariel', B. M. (2005). Patologicheskaya anatomiya lekarstvenno-ustoychivogo tuberkuleza legkikh. Problemy tuberkuleza, 2, 38-40.

[2] Vinokurov, V. I. (2010). Osobennosti morfologicheskikh proyavleniy tuberkuleza legkikh v usloviyakh Kraynego Severa. Byulleten' SO RAMN, 30 (1), 83-37.

[3] Erokhin, V. V. (2003). Molekulyarnye i kletochnye mekhanizmy patogeneza tuberkuleznogo vospaleniya v legkikh. Tuberkuleznye problemy. Saint Petersburg, 141-144.

[4] Vysotskiy, A. G., Mar'yandyshev, A. O. (2009). Lekarstvennaya ustoychivost' mikobakteriy tuberkuleza - aktual'naya problema ftiziatrii: obzor literatury. Problemy tuberkuleza i bolezney legkikh, 7, 3-9.

[5] Bogdanov, V. A., Vorob'ev, A. A., Didenko, D. V. et. al. (2011). Khirurgicheskoe lechenie tuberkuleza. V sbornike nauchnykh trudov posv. 70-letiyu V. I. Litvinova. Moscow, 131-144.

[6] Motus, I. Ya., Golubev, D. N., Bazhenov, A. B. et. al. (2012). Khirurgiya tuberkuleza legkikh. Tuberkulez i bolezni legkikh, 6, 14-20.

[7] Zyuzya, Yu. R., Lepekha, L. N., Gedymin, L. E. et. al. (2006). K voprosu o morfologicheskoy diagnostike lekarstvenno-ustoychivogo tuberkuleza legkikh. Problemy tuberkuleza i bolezney legkikh, $10,56-60$.

[8] Feshchenko, Yu. I., Melnyk, V. M., Zaikov, S. V., Veselovskiy, L. V., Lynnyk, M. I. (2016). Osoblyvosti suchasnoi sytuatsii z tuberkulozu v Ukraini. Ukrainskyi pulmonolohichnyi zhurnal, 1, 5-9.

[9] Shulutko, M. L. (2001). Khirurgicheskoe lechenie tuberkuleza legkikh (opyt i perspektivy). Problemy tuberkuleza, 9, 25-27.

[10] Migliori, G. B. et. al. (2012). The Collaborative Group for Meta-Analysis of Individual Patient Data in MDR - TB. Drug resistance beyond XDR TB : results from a large individual patient data meta-analysis. European Respiratory Journal, 10, 88-95.

[11] Vaniev, E. F. (2008). Effektivnost' khimioterapii vpervye vyyavlennykh bol'nykh destruktivnym tuberkulezom legkikh s lekarstvennoy ustoychivost'yu mikobakteriy tuberkuleza. Moscow, 25.

[12] Feshchenko, Yu. I., Melnyk, V. M., Matusevych, V. H., Novozhylova, I. O., Tarasenko, O. R., Bushura, I. V., Prykhodko, A. M. (2016). Efektyvnist i nedoliky funktsionuvannia protytuberkuloznoi sluzhby v Ukraini. Ukrainskyi pulmonolohichnyi zhurnal, 2, 5-8. 
[13] Moskalenko, V. F., Petrenko, V. I., Radysh, H. V. (2013). Dosiahnennia ta perspektyvy rozvytku ftyziatrii. Tuberkuloz, lehenevi khvoroby, VIL-infektsiia, 1 (12), 5-13.

[14] Feshchenko, Yu. I., Humeniuk, M. I., Denysov, O. S. (2010). Antybiotykorezystentist mikroorhanizmiv: stan problemy ta shliakhy yii vyrishennia. Ukrainskyi khimioterapevtychnyi zhurnal, $1-2,4-10$.

[15] Feshchenko, Yu. I., Melnyk, V. M., Turchenko, L. V. (2016). Pohliad na problemu borotby z tuberkulozom v Ukraini. Ukrainskyi pulmonolohichnyi zhurnal, 3, 5-10.

[16] Khasanshin, G. S., Bizhanova, A. B. et. al. (2011). Khirurgicheskoe lechenie destruktivnogo tuberkuleza u vpervye vyyavlennykh bol'nykh, vydelyayushhikh MBT. Tuberkulez i bolezni legkikh, 5,210 .

[17] Malov, A. A., Vozyakova, T. R., Dmitriev, A. A., Schetchikov, A. N. (2011). Effektivnost' khirurgicheskikh metodov lecheniya bol'nykh tuberkulezom organov dykhaniya Tuberkulez i bolezni legkikh, $5,39-40$

[18] Kang, M.-W., Kim, H. K., Choi, Y. S., Kim, K., Shim, Y. M., Koh, W.-J., Kim, J. (2010). Surgical Treatment for Multidrug-Resistant and Extensive Drug-Resistant Tuberculosis. The Annals of Thoracic Surgery, 89 (5), 1597-1602. doi: http://doi.org/10.1016/j.athoracsur.2010.02.020

[19] Giller, D. B., Shaykhaev, A. Ya., Vasil'eva, I. A., Papkov, A. V. (2008). Effektivnost' chastichnykh rezektsiy legkikh u bol'nykh tuberkulezom s mnozhestvennoy lekarstvennoy ustoychivost'yu. Probl. tuberkuleza i bolezney legkikh, 5, 6-10.

[20] Dheda, K., Giller, D., Kalabukha, I., Kazenniy, B., Krasnov, D., Marrone, M. et. al. (2014).The Role of Surgery in the Treatment of Pulmonary TB and Multidrug-and Extensively Drug-resistant TB. WHO/ Europe Consensus Paper. Available at: http:/www.euro.who.int/en/health-topics/communicable-diseases/tuberculosis/publications/2014/the-role-of-surgery-in-the-treatment-of-pulmonary-tb-and-multidrug-and-extensively-drug-resistant-tb

[21] Marrone, M. T., Venkataramanan, V., Goodman, M., Hill, A. C., Jereb, J. A., Mase, S. R. (2013). Surgical interventions for drug-resistant tuberculosis: a systematic review and meta-analysis. The International Journal of Tuberculosis and Lung Disease, 17 (1), 6-16. doi: http://doi.org/10.5588/ ijtld.12.0198 